\title{
RESPON HARGA BERAS TERHADAP PERMINTAAN BERAS RUMAHTANGGA PETANI KELAPA DI KABUPATEN INDRAGIRI HILIR, PROVINSI RIAU
}

\author{
Elinur $^{1)}$ \\ ${ }^{1)}$ Staf Pengajar Fakultas Pertanian Univeritas Islam Riau, Pekanbaru \\ Email : elinurdjaimi@yahoo.com
}

\begin{abstract}
ABSTRAK
Harga beras sangat menentukan permintaan beras rumahtangga petani kelapa. Penelitian ini bertujuan untuk menganalisis faktor dominan yang mempegeruhi permintaan beras dan respon harga beras terhadap permintaan beras rumahtangga petani kelapa. Penelitian ini menggunakan metode survey. Metode pengambilan mengambil sampel secara multi stage random sampling dan jumlah petani sebanyak 40 orang. Analisis data yang digunakan adalah ekonometrika persamaan tunggal dengan metode estimasi Ordinary Least Square (OLS).

Hasil penelitian menunjukkan bahwa, pertama: factor dominan yang mempengaruhi permintaan beras rumahtangga petani kelapa adalah harga beras, harga ubi, pendapatan rumahtangga dan jumlah anggota petani kelapa. Kedua, Respon harga beras dan harga ubi terhadap permintaan beras rumahtangga petani adalah elastis. Hal ini mengindikasikan bahwa perubahan harga beras dan harga ubi memberikan perubahan yang besar terhadap perubahan permintaan beras rumahtangga petani kelapa. Hal ini mengindikasikan bahwa kebijakan stabilisasi harga beras yang perlu dilakukan oleh pemerintah dalam rangka mengatasi kekurangan pangan karbohidrat pada rumahtangga petani kelapa.
\end{abstract}

Keyword: Respon harga beras, Permintaan Beras dan Rumahtangga petani kelapa

\section{PENDAHULUAN}

Beras merupakan komoditas penting bagi kehidupan masyarakat Indonesia umumnya dan masyarakat Indragiri Hilir khususnya. Konsumsi beras merupakan kebutuhan yang mendasar yang harus dipenuhi oleh individu atau rumahtangga. Konsumsi beras dalam jumlah dan kualitas yang baik sangat diperlukan dalam menentukan asupan gizi bagi kelangsungan hidup manusia. Besarnya konsumsi beras ditentukan jumlah penduduk. Dengan meningkatnya jumlah penduduk tentu akan meningkatkan jumlah konsumsi beras. Data perkembangan penduduk dan 
konsumsi beras di Kabupaten Indragiri Hilir disajikan pada Gambar 1.

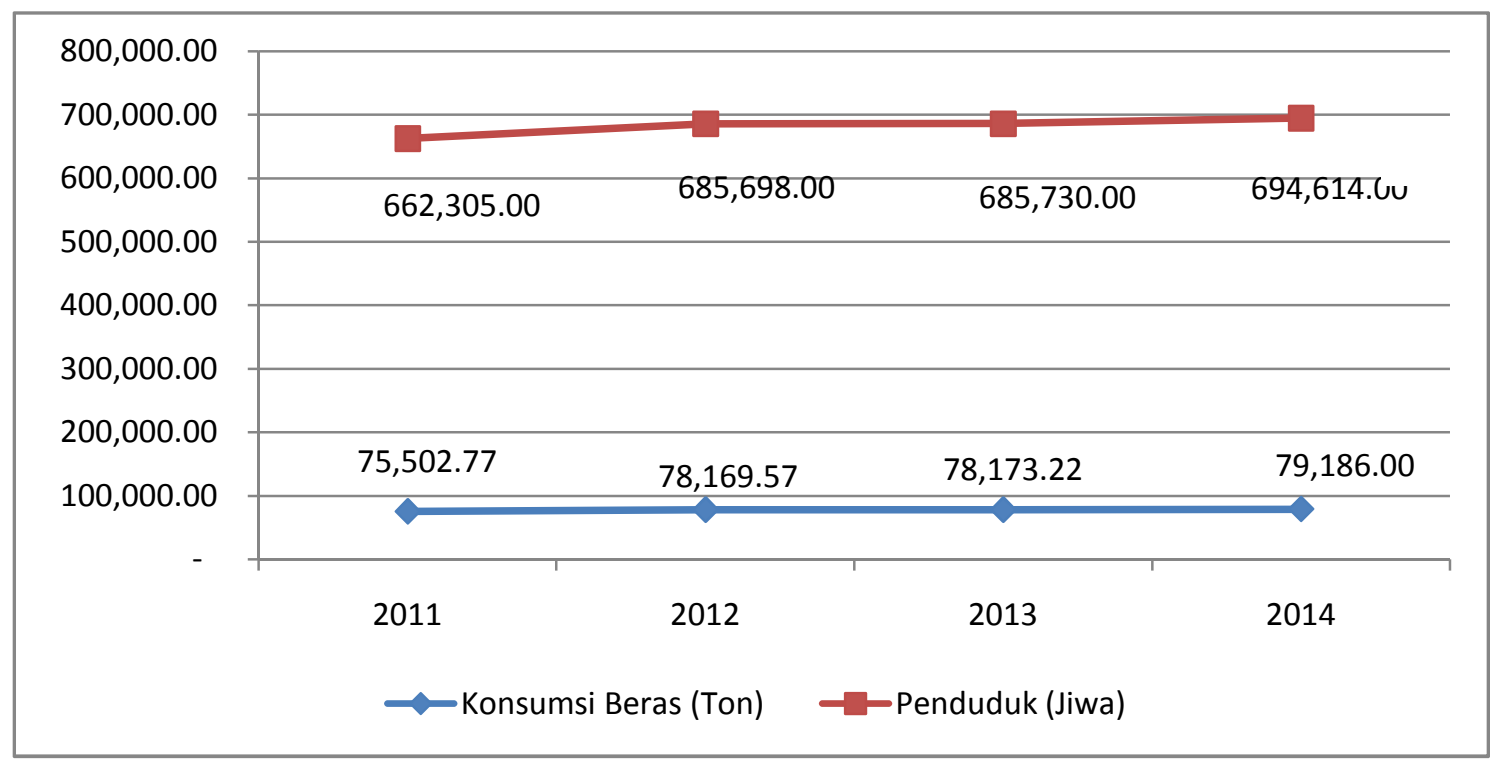

Gambar 1. Konsumsi Beras Kabupaten Indragiri Hilir 2014

Sumber: BPS Indragiri Hilir 2015 dan Survey Sosial Ekonomi Nasional 2012 2015

Berdasarkan Gambar 1 dapat dijelaskan bahwa jumlah penduduk menunjukkan trend yang meningkat, dan konsumsi beras juga demikian. Pertumbuhan penduduk mengalami peningkatan rata-rata 1,71 persen per tahun. Pertumbuhan penduduk Kabupaten Indragiri Hilir termasuk perumbuhan penduduk yang besar dibandingakan dengan pertumbuhan penduduk nasional.

Dengan meningkatnya jumlah penduduk tentu harus diiringi dengan peningkatan produksi beras agar terpenuhi konsumsi beras di Kabupaten Indragiri Hilir. Untuk mencapai tujuan tersebut salah satu cara yang dilakukan oleh Pemerintah Daerah Kabupaten Indragiri Hilir dalam rangka meningkatkan produksi berasnya, melalui Program Peningkatan Produksi Beras Nasional (P2BN) yang diturunkan program pusat. Berdasarkan Data BPS 2012-2014 Kabupaten Indragir Hilir produksi berasnya mengalami peningkatan setiap tahunnya. Hal ini dapat dilihat pada Gambar 2. 


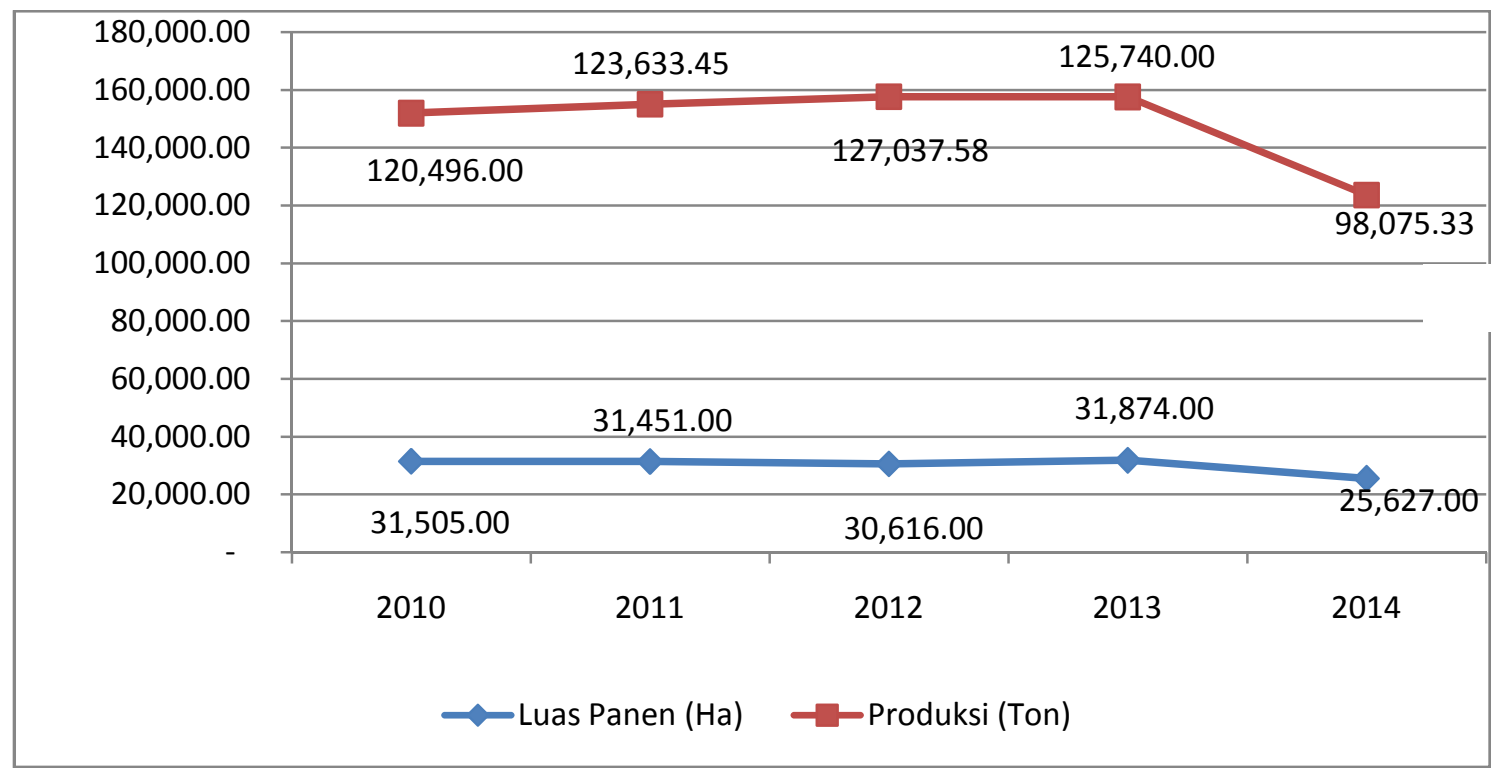

Gambar 2. Produksi Padi Kabupaten Indragiri Hilir 2014

Sumber: BPS Indragiri Hilir 2011 - 2015

Berdasarkan Gambar 2 menunjukkan bahwa produksi padi di Indragiri Hilir mengalami peningkatan dari tahun 2010 sampai 2012, namun mengalami penurunan pada tahun 2013. Penurunan produksi tersebut disebabkan oleh produktivitas padi yang rendah, namun secara rata-rata pertumbuhan padi rata per tahun sebesar 1,4 persen per tahun, dan pertumbuhan luas panen sebesar 0.35 persen per tahun.

Secaraa teoritis, permintaan terhadap dipengaruhi oleh harga komoditas tersebut, harga komoditas lain yang bersifat subsitusi atau komplemen, pendapatan masyarakat, jumlah penduduk, cita rasa dan ramalan mengenai masa yang akan datang (Sugiarto dkk, 2007). Dalam hal ini permintaan beras oleh rumahtangga petani dipengaruhi oleh harga beras, harga komoditas lain yang berhubungan dengan beras, seperti harga ubi, pendapatan masyarakat setempat. Jumlah penduduk di dekati dengan jumlah anggota keluarga. Sedangkan variable selera dalam jangka pendek diasumsikan tidak mengalami perubahan (Bakce dkk, 200; Elinur dan Asrol 2015).

Permasalah utama yang dihadapi dalam permintaan beras adalah peningkatan permintaan beras cenderung meningkat yang diiringi dengan peningkatan jumlah penduduk, namun tidak diiringi dengan pengingkatan produksi beras. Selain itu juga harga beras yang berfluktuatif dan cenderung meningkat, pendapatan masyarakat secara riil tidak mengalami peningkatan. 
Seiring hal tersebut, secara umum tujuan penelitian ini adalah untuk menganalisis factor dominan yang mempengaruhi permintaan beras dan respon harga beras terhadap permintaan beras rumahtangga petani kelapa di Kabupaten Indragiri Hilir.

\section{METODOLOGI PENELITIAN}

Penelitian ini akan dilaksanakan dengan metode survey. Penelitian ini berlokasi di Kecamatan Tempuling, Tembilahan, Kempas, Tembilahan Hulu dan Batang Tuaka Kabupaten Indragiri Hilir. Pemilihan daerah ini dengan pertimbangan bahwa kecamatan tersebut merupakan perwakilan luas perkebunan kelapa dalam dari yang tertinggi sampai yang terendah dan sebagian besar penduduknya bermatapencaharian sebagai petani kelapa. Penelitian dilaksanakan selama 6 bulan dimulai dari bulan Januari sampai dengan Juni 2014.

Populasi dalam penelitian ini adalah petani yang mengusahakan usahatani kelapa dalam dan telah berproduksi di Kabupaten Indragiri Hilir. Pengambilan sampel dilakukan dengan metode multy stage sampling dengan mengambil 5 kecamatan dengan 16 desa di Kabupeten Indragiri Hilir. Kecamatan tersebut adalah Kecamatan Tembilahan, Tembuling, Kempas, Tembilahan Hulu dan Batang Tuaka. Jumlah petani sampel yang diwawancarai sebanyak 40 petani kelapa.

Jenis data yang dikumpulkan adalah data primer cross section (kerat lintang). Data primer diperoleh dari wawancara langsung dengan responden, yaitu rumahtangga petani kelapa dengan menggunakan kuesioner yang telah dipersiapkan. Disamping itu dikumpulkan pula sekunder dari beberapa instansi terkait, seperti Dinas Perkebunan Provinsi dan Kabupaten, Badan Pusat Statistik dan sumber lainnya yang mendukung kegiatan ini.

Penelitian ini memformulasi fungsi permintaan beras rumahtangga petani kelapa. Aanalisis data menggunakan analisis ekonometrika persamaan tunggal. Formulasi fungsi permintaan beras dirumus sebagai berikut:

$\mathrm{QB}=\beta_{0}+\beta_{1} \mathrm{HB}+\beta_{2} \mathrm{HU}+\beta_{3} \mathrm{IRT}+\beta_{4} \mathrm{JAK}+\beta_{5} \mathrm{EP}+\mathrm{e}$ dimana:

$\mathrm{QB}=$ Permintaan beras rumahtangga petani kelapa $(\mathrm{Kg} / \mathrm{bulan})$

$\mathrm{HB}=$ Harga beras $(\mathrm{Rp} / \mathrm{Kg})$

5 Respon Harga Beras Terhadap Permintaan Beras Rumahtangga Petani Kelapa Di Kabupaten Indragiri Hilir, Provinsi Riau 
$\mathrm{HU}=$ Harga Ubi $(\mathrm{Rp} / \mathrm{Kg})$

IRT $=$ Pendapatan rumahtangga petani kelapa $(\mathrm{Rp} / \mathrm{bulan})$

JAK = Jumlah anggota keluarga (orang)

$\mathrm{EP}=$ Pendidikan petani kelapa (Tahun)

$\mathrm{E} \quad=$ Error term

Parameter dugaan yang diharapkan adalah: $\beta_{0}, \beta_{2}, \beta_{3}, \beta_{4}>0$ dan $\beta_{1}, \beta_{5}<0$

Berdasarkan persamaan (1), nilai $\beta_{0}$ sampai $\beta_{5}$ diestimasi dengan metode Ordinary Least Square (OLS). Besarnya pengaruh masing-masing variabel bebas (harga beras, harga ubi, pendapatan rumahtangga, jumlah anggota keluarga dan pendidikan petani) terhadap variabel terikat secara parsial dilakukan uji t. Untuk mengetahui apakah model permintaan beras dikatakan baik menggunakan uji $\mathrm{F}$ dan koefisien determinasi $\left(\mathrm{R}^{2}\right)$. Program yang digunakan untuk mengestimasi nilai parameter dugaan adalah program SAS versi 9.2.

Untuk mengukur respon permintaan beras terhadap faktor yang mempengaruhinya digunakan elastisitas. Elastisitas yang digunakan adalah elastisitas harga, pendapatan dan elastisitas silang dengan rumus sebagai berikut (Sugiarto dkk, 2010):

$\mathrm{p}=\partial \mathrm{QB} / \partial \mathrm{HB} * \mathrm{HB} / \mathrm{Q}$

$$
\mathrm{I}=\partial \mathrm{QB} / \partial \mathrm{I} * \mathrm{I} / \mathrm{Q}
$$

$$
\mathrm{c}=\partial \mathrm{QB} / \partial \mathrm{HU} *
$$

(4)

dimana:

$$
\begin{aligned}
& \mathrm{p}=\text { Elastisitas harga } \\
& \mathrm{I}=\text { Elastisitas pendapatan } \\
& \mathrm{c}=\text { Elastisitas silang }
\end{aligned}
$$

Agar memberikan hasil yang valid secara ekonometrika perlu dilakukan pengujian beberapa asumsi klasik yang meliputi pendektesian normalitas, multicolinearitas dan heteroskedatisitas dari persamaan tersebut. Pendeteksian normalitas menggunakan Shapiro- Wilk tes. Pendeteisan multikolinearitas menggunakan Variance Inflatin Factor (VIF) dan pendeteksian heteroskedatisitas menggunakan White's test (Thomas, 1997 dan Verbeek et al, 2000). 


\section{HASIL DAN PEMBAHASAN}

\section{Faktor Dominan yang Mempengaruhi Permintaan Beras Rumahtangga Petani Kelapa}

Hasil pendugaan model permintaan beras rumahtangga petani kelapa menunujukkan adanya pengaruh peubah variabel bebas terhadap permintaan beras rumahtangga petani kelapa. Hasil pendugaan model permintaan beras rumahtangga petani kelapa menunjukkan semua variabel bebas signifikan mempengaruhi permintaan beras rumahtangga petani kelapa, kecuali pendidikan petani. Estmasi model permintaan beras rumahtangga petani kelapa ditunjukkan pada Tabel 1.

Tabel 1. Hasil Estimasi Model Permintaan Beras Rumahtangga Petani Kelapa Kabupaten Indragiri Hilir Provinsi Riau Tahun 2014

\begin{tabular}{|l|r|r|r|}
\hline \multicolumn{1}{|c|}{ Variabel } & \multicolumn{1}{c|}{$\begin{array}{c}\text { Parameter } \\
\text { Estimasi }\end{array}$} & T Value & $\operatorname{Pr}>|\mathrm{t}|$ \\
\hline Intercept & 217.1351 & 6.89 & $<.0001$ \\
\hline Harga Beras (HB) & -0.0132 & -6.06 & $<.0001$ \\
\hline Harga Ubi (HU) & -0.0093 & -6.69 & $<.0001$ \\
\hline Pendapatan RT (IRT) & $7.60 \mathrm{E}-08$ & 0.89 & 0.0809 \\
\hline Jumlah Anggota Keluarga (JAK) & 1.3132 & 1.9 & 0.0659 \\
\hline Pendidikan Petani (EP) & -0.1001 & -0.74 & 0.4637 \\
\hline
\end{tabular}

Berdasarkan Tabel 1 dijelaskan bahwa semua variabel bebas yang dimasukkan kedalam model signifikan mempengaruhi permintaan beras, kecuali variabel pendidikan petani. Harga beras dan harga ubi berpengaruh negatif dan signifikan terhadap permintaan beras rumahtangga petani kelapa pada tarap nyata masing-masing sebesar 0.1 persen. Sedangkan pendapatan rumahtangga dan jumlah anggota keluarga berpengaruh positif dan signifikan mempengaruhi permintaan beras rumahtangga petani pada taraf nyata 20 persen dan 6 persen.

Selanjunya, nilai parameter estimasi harga beras dan ubi masing-masing sebesar 0,0132 dan 0.0093. Nilai 0,0132 memiliki arti apabila harga beras meningkat sebesar satu-satuan maka permintaan beras akan turun sebesar 0.0132 kg dan nilai 0.0093 memiliki arti apabila harga ubi meningkat sebesar satu-satuan maka permintaan beras akan turun sebesar $0.0093 \mathrm{~kg}$. Sebaliknya, apabila jumlah

7 Respon Harga Beras Terhadap Permintaan Beras Rumahtangga Petani Kelapa Di Kabupaten Indragiri Hilir, Provinsi Riau 
anggota keluarga meningkat sebesar satu-satu maka permintaan beras akan meningkat sebesar $1,3 \mathrm{~kg}$.

\section{Uji Asumsi Klasik}

Dalam analisis regresi linier berganda yang diestimasi dengan menggunakan menggunakan metode Ordinary Least Square (OLS) akan melanggar asumsi-asumsi klasik. Asumsi-asumsi klasik tersebut seperti normalitas, multikolinearitas, heterosekedastisitas dan autokorelasi. Untuk mengatasi hal tersebut dilakukan uji normalitas, multikolinearitas, heterosekedastisitas dan outokorelasi dengan menggunakan program Statistical Analysis System (SAS) versi 19. Hasil uji asumsi ekonometrik disajikan pada Tabel 2.

Tabel 2 menunjukkan hasil uji normalitas dengan menggunakan ShapiroWilk test dan heteroskedatisitas dengan White's test menyatakan koefisienkoefisien penduga dalam penelitian ini signifikan pada tingkat kepercayaan sebesar 10 persen. Artinya model permintaan beras rumahtangga terdistribusi secara normal dan tidak terjadi heteroskedatisitas. Demikian halnya dengan uji multikolonerias dan autokorelasi dengan menggunakan Variance Inflation factor (VIF) dengan nilai dibawah 10 dan Durbin Watson test menyatakan tidak terjadi multikolineartas dan autokorelasi.

Tabel 2. Uji Asumsi Klasik Model Permintaan Beras Rumahtangga Petani Kelapa Kabupaten Indragiri Hilir Provinsi Riau Tahun 2014

\begin{tabular}{|c|l|l|c|c|}
\hline No & \multicolumn{1}{|c|}{ Uji Asumsi Klasik } & Test Statistik & $\begin{array}{c}\text { Statistic } \\
\text { Value }\end{array}$ & Probability \\
\hline 1. & Uji Normalitas & Shapiro-Wilk & 0.99 & 0.09 \\
\hline 2. & Uji Multikolinearitas & VIF & $\begin{array}{c}1.278- \\
6.304\end{array}$ & - \\
\hline 3 & UJi Heteroskedastisitas & White's Test & 34.75 & 0.02 \\
\hline 4. & & Durbin & & - \\
\hline
\end{tabular}

\section{Respon Permintaan Beras Rumahtangga Petani Kelapa Terhadap Faktor yang Mempengaruhinya}


Respon permintaan beras rumahtangga petani kelapa terhadap factor yang mempengaruhinya diukur dengan elastisitas. Elastisitas adalah perubahan suatu variable yang disebabkan oleh perubahan variable lain dalam ukuran persen. Respon permintaan beras terhadap perubahan harga disebut dengan elastisitas harga. Respon Perubahan harga komoditas mempuyai dua efek, efek subsitusi dan efek pendapatan. Efek subsitusi adalah perubahan dalam mengkonsumsi suatu komoditas tersebut atau komoditas lain dengan tingkat utilitas yang konstan. Efek pendapatan terjadi karena perubahan harga suatu komoditas menyebabkan adanya perubahan terhadap kekuatan daya belinya. Respon permintaan beras terhadap perubahan harga ubi disebut dengan elastisitas silang dan respon permintaan beras terhadap perubahan pendapatan rumahtangga disebut dengan elastisitas pendapatan (Income). Respon permintaan beras terhadap faktor yang mempengaruhinya disajikan pada Tabrl 3.

Tabel 3. Respon Permintaan Beras Rumahtangga Petani Kelapa Kabupaten Indragiri Hilir Provinsi Riau Tahun 2014

\begin{tabular}{|l|c|c|}
\hline \multicolumn{1}{|c|}{ Variabel } & Simbol Variabel & Elastisitas \\
\hline Harga Beras & HB & -4.701 \\
\hline Harga Ubi & HU & -1.267 \\
\hline Pendapatan RT & IRT & 0.007 \\
\hline Jumlah Anggota Keluarga & JAK & 0.199 \\
\hline Pendidikan Petani & EP & -0.034 \\
\hline
\end{tabular}

Tabel 3 menunjukkan bahwa elastisistas harga beras terhadap permintaan beras dan elastistas silang harga ubi terhadap permintaan beras elastis, karena besar dari 1. Nilai elastisitas harga beras terhadap permintaan beras sebesar 4,701. Hal ini berarti apabila harga beras meningkat 1 persen maka permintaan beras akan turun sebesar 4,701 persen. Demikian juga elastisita harga ubi terhadap permintaan beras sebesar 1,267, artinya adalah apabila harga ubi naik sebesar 1 persen maka permintaan beras akan turun sebesar 1,267 persen. Elastisitas harga beras dan harga ubi terhadap permintaan beras adalah elastis. Hal ini mengidindikasikan bahwa respon harga beras dan harga ubi memberikan perubahan yang besar terhadap perubahan permintaan beras.

Sebaliknya, Tabel 3 menunjukkan elastisitas pendapatan dan jumlah anggota keluarga petani kelapa terhadap permintaan beras adalah inelastis, kaena

9 Respon Harga Beras Terhadap Permintaan Beras Rumahtangga Petani Kelapa Di Kabupaten Indragiri Hilir, Provinsi Riau 
nilai elastisitas kecil dari 1. Hal ini menunjukkan bahwa respon pendapatan dan jumlah anggota keluarga petani kelapa memberikan perubahan yang kecil terhadap perubahan permintaan beras rumahtangga petani kelapa.

\section{KESIMPULAN DAN IMPLIKASI KEBIJAKAN}

Berdasarkan hasil estimasi menunjukkan bahwa factor dominan dan signifikan yang mempengaruhi permintaan beras rumahtangga petani kelapa adalah harga beras, harga ubi, pendapatan dan jumlah anggota rumahtangga petani kelapa. Harga beras dan ubi berpengaruhi negatif terhadap permintaan beras, sedangkan pendapatan dan jumlah anggota rumahtangga petani kelapa berpengaruhi positif. Respon harga beras dan harga ubi terhadap permintaan beras rumahtangga petani kelapa adalah elastis. Hal ini mengindikasikan bahwa perubahan harga beras dan harga ubi memberikan dampak yang besar terhadap perubahan permintaan harga beras rumahtangga petani kelapa.

Dari hasil temuan ini menunjukkan bahwa harga beras sangat menentukan besarnya jumlah beras yang akan dikonsumsi oleh rumahtangga petani. Oleh karena itu implikasi kebijakannya perlunya stabilisasi harga beras dari Pemerintah untuk mengatasi kekurangan pangan karbohidrat pada rumahtangga petani kelapa di Kabupaten Indragiri Hilir.

\section{DAFTAR PUSTAKA}

Badan Pusat Statistik Kabuapaten Indragiri Hilir. 2014. Kabuapaten Indragiri Hilir dalam Angka. Badan Pusat Statistik Kabuapaten Indragiri Hilir, Tembilahan.

Bakce, D; Heriyanto dan Elinur (2012). Dampak Pengendalian Harga dan Peningkatan Pendapatan Terhadap Pengeluaran Konsumsi Pangan Pokok Rumahtangga di Provinsi Riau. Prosiding: Penguatan Agribisnis Perberasan Guna Menwujudkan Kemandirian dan Kesejahteraan Petani. Magister Managemen Agribisnis Universitas Gadjah Mada Bekerja sama dengan Perhimpunan Ekonomi Pertanian Indonesia.

Elinur dan Asrol. 2015. Dampak Harga Beras Terhadap Konsumsi Beras Rumahtangga Petani Kelapa Sawit di Desa Indra Sakti Kecamatan Tapung Kabupaten Kampar. Indonesian Journal of Agriculture Economics 6 (1): 111 .

Thomas, R.L1997. Modern Microeconomics an Introduction. Addison Wesley Longman, Harlow.

10 Respon Harga Beras Terhadap Permintaan Beras Rumahtangga Petani Kelapa Di Kabupaten Indragiri Hilir, Provinsi Riau 
Sugiarto, Tedy Herlambang, Brastoro, Rahmat Sudjana dan Said Kelana, 2010. Ekonomi Mikro: Sebuah Kajian Komprhensih. Edisi Kelima. PT. Gramedia Pustaka Utama, Jakarta.

Verbeek, M., KU Leuven, and Tilburg University, 2000. A Guide to Modern Econometrics. John Wiley \& sons Ltf., Chichester. 